\title{
Does Innovative Financing Increase the Firm Performance? An Empirical Investigation of Indian Manufacturing Firms
}

\author{
Narender Vunyale, Nemi Raja, Raveesh Krishnankutty \\ Department of Finance \& Accounting, ICFAI Business School, Hyderabad, IFHE University, Hyderabad, India \\ Email: narender.vunyale@gmail.com,nemiraja@ibsindia.org, raveeshbabu@gmail.com
}

Received 1 April 2016; accepted 24 April 2016; published 27 April 2016

Copyright (C) 2016 by authors and Scientific Research Publishing Inc.

This work is licensed under the Creative Commons Attribution International License (CC BY).

http://creativecommons.org/licenses/by/4.0/

cC) (7) Open Access

\begin{abstract}
The firms mobilizing resources using innovative debt from market reduce dependence on the traditional banking and financial institutions. The firms raising resources by directly approaching public have some incentive to do so, i.e., innovative firms will be able to better plan commitments of future cash outflow and inflow, increase the borrowing capacity, save taxes, etc. to create higher value to the shareholders. In this paper we have made an attempt to test whether such innovative firms' performance is higher than other firms. We also tried to understand if more variety of instruments helped create better value of share in the market for such firms.
\end{abstract}

\section{Keywords}

Firms' Performance, Innovative Firms', Innovative Financing, Innovative Debt, Value of Firm, Indian Manufacturing Firm

\section{Introduction}

A sharp acceleration in the pace of liberalization, deregulation and stabilization and structural adjustment programs (S\&SAP) of different countries in the world in the eighties and nineties has transformed the financial systems in many countries. One of the major changes observed in the national and international finance is the innovation in the management of finance leading to the floatation of innovative financial instruments or tapping untapped (non-traditional) markets. [1] observed that "financial markets have witnessed a transformation with very vital trends, namely, globalization, securitization, and sophistication of risk management all over the world and enabled the participants in the financial markets to innovate and create innovative financial products and mobilize large chunk of funds”. 
There are two important arguments existing and are expressed across the world. The bank based view that holds and supports bank based systems, argues that bank based financial system, particularly at early stages of economic development will foster economic growth to a greater degree than market based systems. The market based view emphasizes that markets provide key financial services that stimulate innovation and long run growth [2].

Firms accessing the financial markets tend to innovate and sell innovative financing instruments in the process of creation of market value. [3] observed that there would be no incentive to innovate if the financial innovations and financing tactics have not added value to the firm. [4] observed that the past has witnessed "a stream of innovation in financial markets, particularly in the corporate bond arena, and some of these innovations are designed to give firms flexibility in designing cash flows on borrowings, allowing them to match up cash flows on financing more closely to cash flows on assets, thus increasing their debt capacity”. Financial markets have been continuously witnessing innovations in the design of securities and new financing schemes and innovations proving that "financing matters" [5]. Financial innovation is nothing but unbundling and repacking of the lending and borrowing characteristics to suit the day-to-day and modern requirements. Innovation is designed to suit the various needs like liquidity, cost of finance, maturity period, character of negotiable instruments, securitized and non-securitized periodicity of interest payments, asset security and others. Innovations in financing instruments are made out to materialize the financing strategies which are required for the smooth running of the businesses.

The financial markets in the recent past have witnessed a stream of innovation in financial markets, particularly in corporate bonds. Financial innovations, notably, hybrid debt have provided firms with more flexibility in designing cash flows on borrowings, allowing them to match cash flows on financing more closely to cash flows of the assets. Matching of the cash inflows and outflows on the basis of investments in assets allows firms to use innovative securities and this approach has increased corporate debt capacity and hence firm value. The firms with high growth opportunities, cash holdings, cash flow volatility, research and development expenses, and advertising expenses, and firms with unique products and a strong board, specialize in a few types of debt, while large, mature, profitable firms with more tangible assets, high leverage, and a credit rating use multiple sources $[6]$.

[7] observed that despite the limited supply of bank and market finance in developing countries, traditional debt is the preferred form of finance over alternative finance, and better firms with access to banks and markets grow faster. There is a prevalence of alternative institutions and finance in the Indian economy; equally important question is whether alternative finance is as conducive as a bank or market finance in supporting growth. The study finds that bank and market finance, backed by legal institutions, may not be superior to alternative finance, backed by non-legal mechanisms, in fast growing economies such as India.

The initial fixed costs of alternative finance such as trade credits are high up till a network of firms; customers and investors are created; after that the average costs over an extended period may be lower than the costs of market and bank finance based on the relationships that the firm establishes [8]. [9] argued that in fast growing economies like India, alternative finance, by not using the legal system, can minimize the many costs associated with legal institutions and better adapt to changes than legal institutions.

On account of the above arguments our paper makes an attempt to answer the following questions:

- Will the firm value be higher if the firm access financial markets using innovative financing instruments? [3] argued that firms do not innovate without incentive and [4] argued that innovative financing instruments enable firms to plan and match cash flows to enable better performance. In such case, will the firms using innovative instruments and accessing debt through instruments have higher value? Hence we make an attempt to look at will the firms using innovative financing instruments perform better in comparison with firms that access the traditional debt or take the route of banks and financial institutions. To test the same, we have following two hypotheses: one based on market performance of the firm and the other based on the firm performance internally.

a) Firms using innovative methods of financing (innovative firms) do they perform better-is the ROA of the innovative firms using innovative instruments higher in comparison to firms using traditional debt; (will ROA of innovative firms be higher than that of lesser innovative firms?).

b) The firms accessing market to finance their debt are expected to be frequently going to the public and should have higher transparency; therefore "the market value of the innovative firms will be greater than that of lesser innovative firms”. 


\section{Variables}

MVBV = market value equity/book value of equity.

ROA = profit after tax (PAT) upon the total assets invested (TA).

Growth = growth in total assets $=$ (total assets - L. total assets $) /$ L. total assets.

Tangibility $=$ net fixed assets/total assets.

Size $=$ natural logarithm of sales.

L_TDR = one year lagged value of (total debt/total assets).

NTDS $=$ non debt tax shield $=($ depreciation + amortization $) /$ total assets.

Market Innovation = we define market innovation in terms of the number of market debt instruments that a firm used to finance ${ }^{1}$. The type of debt instruments considered are debentures or bonds (secured/unsecured); commercial paper; fixed deposits from public (unique to India); external commercial borrowing; leasing and hire-purchase.

\section{Data}

The data required for the study are downloaded from one of the India's prominent databank sources of corporate data for the academic research, i.e. Center for Monitoring Indian Economy (CMIE-Database). The company has India's largest database built on the financial performance of individual firms and most researchers on Indian sample use the database. The sample includes only the listed firms on any of the stock exchanges in India, since hypothesis number one stated above cannot be tested for the unlisted firms. An unbalanced panel data for the study period to test the hypotheses is taken from the year 2000-2014 and the year 2000 is excluded from using the lagged variables and finally 14 years for 1753 companies with an average of 12.5 years data are taken.

\section{Research Methodology}

In the last two decades, the literature on financing behaviour has seen a major shift from macro modelling towards micro modelling of financing. For micro modelling, the use of Panel Data models is of major significance, as it takes care of the various econometric problems associated with other models like time series and cross section models. A panel data set is one that follows a given sample of individuals over time, and thus provides multiple observations on each individual in the sample. Panel data sets for economic research possess several major advantages over conventional cross-sectional or time-series data sets. By using information on both the intertemporal dynamics and the individualities of entities being investigated, one is better able to control in a more natural way the effects of missing or unobserved variables. Longitudinal data allow a researcher to analyse a number of important economic questions that cannot be addressed using cross-sectional or time-series data sets alone. The other advantage of panel data set is that it controls the individual heterogeneity and therefore the risk of obtaining biased results is minimized. Panel data are given more information, more variability, less collinearity among the variables, more degree of freedom, and more efficiency. It is sometimes argued that cross-section data reflect short-run behaviour, while time series data emphasize long-run effects. By combining the two sets of information, one can study the dynamics of economic behaviour at an individual level. The panel data set is said to be better able to identify and measure effects that are simply not detectable in pure cross-section or time series data set. Panel data models allow us to construct and test more complicated behavioural models than purely cross-section and time-series data. In other words, it can be said that the technical efficiency of the economic behaviour is better studied and modelled with panel data. Panel data estimation yields more robust effects of independent variables on the dependent variables than the time-series estimation.

A Fixed Effects unbalanced panel data ${ }^{2}$ model is used to test whether the performance and Market Value of the firms that are issuing the debt in the market using the instruments like Debentures and Bonds, Commercial Paper, Public Deposits or using non-bank debt source like Leasing and Hire Purchase and Foreign Commercial borrowings is higher in comparison with the firms that are not using this set of sources in the overall debt structure of the firm.

\footnotetext{
${ }^{1}$ It is measured using a scale of 0 - 5; Zero being no market debt firm and 5 being a firm which uses five different sources of market based debt, i.e Debentures or Bonds (Secured/unsecured); Commercial Paper; Fixed Deposits from Public (unique to India); External Commercial Borrowing; Leasing and Hire-Purchase.

${ }^{2}$ Based on the Hausman Test.
} 
Accordingly hypothesis are drawn on the basis of return on assets as one of the best parameters to measure performance of a firm, though it is based on the accounting result and not a market performance parameter unlike the Tobin's Q ratio. This variable takes a dependent variable and is tested to understand whether the ROA of the firms' using market sources to finance have higher ROA than those firms' that are purely depending on the traditional banking and financial institutions to source for their financial requirements in the overall debt that they are borrowing. To test the same following equation is drawn:

$$
\begin{aligned}
& R O A_{I J T}=\alpha_{i}+\beta_{1} \text { Growth }_{i j t}+\beta_{2} \text { Tangibility }_{i j t}+\beta_{3} \text { Size }_{i j t}+\beta_{4} T D R_{i j t-1} \\
& +\beta_{5} \text { NDTS }_{i j t}+\beta_{6} \text { Age }_{i j t}+\beta_{7} \text { Market_Inno }_{i j t}+U_{i j t} \\
& M V B V_{i j t}=\alpha_{i}+\beta_{1} \text { Growth }_{i j t}+\beta_{2} \text { Tangibility }_{i j t}+\beta_{3} \text { Size }_{i j t}+\beta_{4} R O A_{i j t-1} \\
& +\beta_{5} T_{D R} R_{i j t-1}+\beta_{6} \text { NDTS }_{i j t}+\beta_{7} \text { Age }_{i j t}+\beta_{8} \text { Market_Inno }_{i j t}+U_{i j t} \\
& R O A_{i j t}=\alpha_{i} \text { Growth }_{i j t}+\beta_{2} \text { Tangibility }_{i j t}+\beta_{3} \text { Size }_{i j t}+\beta_{4} T D R_{i j t-1} \\
& +\beta_{5} \text { NDTS }_{i j t}+\beta_{6} \text { Age }_{i j t}+\beta_{7} \text { Market_Dum }_{i j t}+U_{i j t} \\
& M V B V_{i j t}=\alpha_{i}+\beta_{1} \text { Growth }_{i j t}+\beta_{2} \text { Tangibility }_{i j t}+\beta_{3} \text { Size }_{i j t}+\beta_{4} R O A_{i j t-1}+\beta_{5} T D R_{i j t-1} \\
& +\beta_{6} \text { NDTS }_{i j t}+\beta_{7} \text { Age }_{i j t}+\beta_{8} \text { Market_Inno }_{i j t}+U_{i j t}
\end{aligned}
$$

where $R O A_{i j t}$ stands for ROA of $i^{\text {th }}$ firm belonging to $j^{\text {th }}$ industry and year " $t$ " To understand and test the hypothesis that the firms using these market oriented instruments will have higher market value to book value ratio the model (2) and (4) is used, where $M V B V_{i j t}$ stands for MVBV of $i^{\text {th }}$ firm belonging to $j^{\text {th }}$ industry and year " $t$ ".

The coefficients of the above models are estimated using OLS procedure and the method is corrected for heteroskedasticity and endogeneity.

The dependent variables as expressed in the equations one and two are market value to book value and return on assets of the firm. The market value to book value otherwise known as Tobin's Q is expected to be influenced by the type of borrowings the firm is using to finance using debt. [10] observe that the financial instrument like commercial paper offers firms cheapest source of short-term financing for well rated and large wellestablished firms in a typical natural environment. This argument supports two arguments, the first being the firms accessing market to source debt will have cheaper sources of finance to enhance the value of the firm and the second being firms with large size (measured as natural log of sales) can access market to source finances easily than that of counterparts whose size is not so large.

[11] develop a framework to estimate the ability of cash flow to predict its ability to reduce credit friction or act as a financial accelerator, and observe that the firms with access to the commercial paper and bond markets in a perfect capital market model of investment, the cash flow is smoother and investment appears to be much more sensitive in the firms with fluctuations in cash flow. Thus concluding the role of cash flow in investment equations and provide support for the existence of a financial accelerator which should enhance the value of the firm in the market. The study focuses on the choice of securities and the composition of debt, and observes that access to the commercial paper market enhances financial flexibility by providing a source of financing that can be used to undertake new investment opportunities and provide empirical validation of a common assumption that commercial paper issuers face fewer financial constraints than other firms.

One of the other parameters, used generally to measure the performance of the firm being Return on Assets measured as profit after tax upon the total assets invested in the business. The tangibility of fixed assets enhances the ability to borrow more either from the banks or from the markets by selling securities. Banks and financial institutions will lend swiftly when the firm has a collateral in the form of fixed assets and higher the tangible assets the firm has will be able to borrow more from the banks and financial institutions. In contrast, the firms with higher amount of fixed tangible assets have higher bargaining power to borrow from the banks at a cheaper rate; hence the market borrowing may be low. In the similar manner, the size of the firm and age play a similar role in deciding and borrowing hence there could be a negative relationship between the market borrowings and debt. On the other hand, it could be of quiet an opposite experience if, the managers of the firm use these features of tangibility, age and size of the firm to make them use to borrow from the market in place of banks-there could be a positive relationship of the debt with these variables.

[12] observe that large sized firms tend to be more diversified and less prone to bankruptcy; this argument 
suggests that large firms should be more highly leveraged. In the study impact of the leverage on the market value of the share is found to be insignificant in all the three samples. This reveals that there is a positive relationship of size, but the market value is not influenced significantly by the size of the firm.

Growth of the firm by using growth of total assets of the firm and it requires to be supported with sufficient finances. The debt would increase as the growth of the firm increases and expected to have a positive relationship with the leverage. The borrowings of the firm could be either by using traditional debt or market debt. [13] observe that lower the non-debt tax shield of the firm in the form of depreciation and amortizations along with tax allowance higher will be the issue of debt by the firm. The non-debt tax shields are the substitutes for the tax benefit that can be derived from debt financing, when the NDTS (Non Debt Tax Shield measured as Depreciation, Amortization and Write-offs) is not available firms tend to go for more debt and attempt to derive tax benefit (Table $1 \&$ Table 2).

\section{Results and Analysis (Model 1 \& 2)}

The variables ROA and MVBV (Table 3) are used as dependent variables and regression is run to test whether the innovative firms accessing, using debt by issuing various instruments have better performance over the other firms that use traditional debt in their leverage. The independent primary variable is measured as a dummy by marking " 1 " for the firms issuing debt in the market and " 0 " for firms using only traditional debt (includes the firm with no or zero debt).

Table 1. Descriptive statistics of the variable.

\begin{tabular}{cccccc}
\hline Variable & Obs & Mean & Std.Dev. & Min & Max \\
\hline MVBV & 22,708 & 1.605 & 3.022 & 0.008 & 49.803 \\
GROWTH & 22,708 & 0.115 & 0.236 & -0.972 & 1.498 \\
TANGIBILITY & 22,506 & 0.326 & 0.198 & 0.000 & 0.994 \\
SIZE & 21,940 & 6.732 & 2.211 & 0.000 & 15.205 \\
L_TDR & 22,708 & 0.280 & 0.212 & 0.000 & 3.771 \\
L_ROA & 22,708 & 0.038 & 0.221 & -25.125 & 6.383 \\
ROA & 22,708 & 0.036 & 0.096 & -0.971 & 1.449 \\
NTDS & 22,708 & 0.031 & 0.023 & 0.000 & 0.550 \\
MARKET_INNO & 22,708 & 0.601 & 0.841 & 0.000 & 5.000 \\
AGE & 22,708 & 30.466 & 19.764 & 5.000 & 151.000 \\
TDR & 22,708 & 0.274 & 0.202 & 0.000 & 0.952 \\
\hline
\end{tabular}

Table 2. Pairwise correlation among the variables.

\begin{tabular}{|c|c|c|c|c|c|c|c|c|c|c|c|}
\hline & Mvbv & Growth & Tangibility & Size & L_tdr & L_roa & Roa & Ntds & Market_inno & Age & $\mathrm{Tdr}$ \\
\hline MVBV & 1.00 & & & & & & & & & & \\
\hline GROWTH & 0.10 & 1.00 & & & & & & & & & \\
\hline TANGIBILITY & -0.09 & -0.11 & 1.00 & & & & & & & & \\
\hline SIZE & 0.14 & 0.19 & 0.00 & 1.00 & & & & & & & \\
\hline L_TDR & -0.04 & -0.02 & 0.36 & 0.19 & 1.00 & & & & & & \\
\hline L_ROA & 0.04 & 0.10 & -0.07 & 0.15 & -0.09 & 1.00 & & & & & \\
\hline ROA & 0.13 & 0.29 & -0.09 & 0.22 & -0.05 & 0.19 & 1.00 & & & & \\
\hline NTDS & -0.01 & -0.17 & 0.53 & 0.02 & 0.20 & -0.01 & -0.07 & 1.00 & & & \\
\hline MARKET_INNO & -0.02 & 0.06 & 0.16 & 0.42 & 0.32 & -0.01 & -0.03 & 0.06 & 1.00 & & \\
\hline AGE & 0.13 & -0.01 & -0.05 & 0.34 & -0.02 & 0.04 & 0.09 & -0.10 & 0.24 & 1.00 & \\
\hline TDR & -0.05 & 0.05 & 0.35 & 0.21 & 0.87 & -0.09 & -0.23 & 0.17 & 0.35 & -0.02 & 1.00 \\
\hline
\end{tabular}


Table 3. Market debt and firm performance.

\begin{tabular}{|c|c|c|c|c|c|c|}
\hline \multirow{2}{*}{ Variable } & \multicolumn{3}{|c|}{ ROA } & \multicolumn{3}{|c|}{ MVBV } \\
\hline & Total & Sample I & Sample II & Total & Sample 1 & Sample II \\
\hline Growth & $0.075^{* * * *}$ & $0.053^{* * *}$ & $0.083^{* * * *}$ & $0.696^{* * *}$ & $0.709^{* * *}$ & $0.502^{* * *}$ \\
\hline Tangibility & $-0.058^{* * *}$ & $-0.038^{* * *}$ & $-0.073^{* * *}$ & -0.318 & $-0.736^{* *}$ & -0.244 \\
\hline Size & $0.012^{* * *}$ & $0.013^{* * *}$ & $0.015^{* * *}$ & 0.028 & 0.058 & 0.051 \\
\hline L_TDR & $0.090^{* * *}$ & 0.006 & $0.159^{* * *}$ & $1.241^{* * *}$ & $1.203^{* * *}$ & $1.421^{* * *}$ \\
\hline L_ROA & & & & 0.032 & 0.687 & -0.213 \\
\hline NDTS & $-0.265^{* *}$ & -0.079 & $-0.368^{* *}$ & 2.227 & $4.611^{*}$ & 0.544 \\
\hline Age & $0.018^{* * *}$ & $0.017^{* * *}$ & $0.002^{* * *}$ & $-0.054^{* * *}$ & $-0.055^{* * *}$ & $-0.040^{* * *}$ \\
\hline Market_Inno & $-0.018^{* * *}$ & $-0.011^{* * *}$ & & $-0.189^{* * *}$ & -0.072 & \\
\hline Constant & $-0.039^{* * *}$ & $-0.042^{* * *}$ & $-0.049^{* * *}$ & $0.406^{* * *}$ & -0.049 & $0.475^{*}$ \\
\hline Number of obs. & 21,863 & 9309 & 12554 & 21,863 & 9309 & 12554 \\
\hline Number of groups & 1753 & 1249 & 1480 & 1753 & 1249 & 1480 \\
\hline Overall & 0.094 & 0.0457 & 0.0865 & 0.035 & 0.0457 & 0.0214 \\
\hline F-statistic & $43.59^{* * *}$ & $30.51^{* * *}$ & $20.91^{* * *}$ & $43.59^{* * *}$ & $30.51^{* * *}$ & $20.91^{* * *}$ \\
\hline
\end{tabular}

Note: $1 .{ }^{* * *},{ }^{* *},{ }^{*}$ indicates $1 \%, 5 \%$ and $10 \%$ level of significances respectively, 2 . Sample I: Companies which are only having market debt. Sample II: companies which are only having traditional debt.

The answer to the question as to will the firms using debt from the market have better performance over the other firms, we got from the sample is a big "No". The performance of the firm does not increase with the use of market debt by firms. The firms using debt raised from the market using various instruments like debentures, public deposits, commercial paper, leasing and Hire purchase, etc. have a poorer performance earning lesser $\mathrm{ROA}$ in comparison with the firms accessing traditional debt which include debt raised from banks and financial institutions

The second performance measure evaluating market performance too, the results reveal that the value of the firms those issuing debt in the market with innovative instruments is lesser than that of firms using traditional debt. The general behaviour should have been that of firms using innovative debt should have been more transparent than that of the other firms, but in the Indian context the firms using innovative instruments are not able to win the confidence of investors in terms of better transparency. The reason could be that the firms raising debt from the market have higher cost of issue or it could be that the ability to negotiate and mobilize debt from banks at a cheaper rate than what they could raise from the market. [4] in his paper observed that "the increase in value and performance of the firm will not come from innovative debt just by fooling the bond buyers as the investors in such securities will certainly charge appropriate premiums over the interest rate. He further argues that the increase in value for the firm will come from the increase in debt capacity that allows the firm to have a larger tax benefit with lower expected bankruptcy costs”.

Growth and size in both the cases have revealed a positive significant relationship. In the case of age the result revealed that the internal performance variable ROA is positively significant (as expected), whereas the market based performance variable is negatively significant (investors investing in innovative firms charge higher discount if they do not understand the financing instruments well irrespective of the size of the firm).

The fixed corporeal assets enable the firm to borrow more and in turn the ability and flexibility to raise either from the traditional sources or take the advantage from the dynamics of the debt market. But, this in turn demand for depreciation and establishment expenses and may lead to decrease in profitability with higher depreciation on new assets, unless the scale of operations is not achieved. In both cases the results reveal that there is a significant negative relationship. The variable Non-debt tax shield (NDTS) showed significant impact on ROA whereas for MVBV it is found to be insignificant.

When we have observed the firms using scale on the variety of instruments used (market debt), it is observed 
that the average market value to book value for firms using no debt is higher than the firms using one instrument, the firms using one instrument is higher than two instruments, but the firms using three instruments is higher than four instruments and the firms using four instruments is less than three instruments and the firms using five variety instruments is higher than all the other firms (refer Table 4 showing Market Value to Book Value, Return on Assets in case of Firms Using Multiple Market Debt Instruments and Traditional Debt along with Total Debt). Further, to understand do the firms using higher number of debt instruments have higher MVBV or ROA, we divided the sample into three groups, the first being whole sample consisting of firms using both traditional $\operatorname{debt}^{3}$ and innovative debt from market (with scale of " 0 to 6 " for traditional debt and " 0 to 5 " for market debt), the second consisting only the firms using innovative debt and third with the firms using only traditional sources of debt. Then, we have tested the hypothesis that the higher the number of debt instruments higher will be the performance of the firm i.e. higher number of debt instruments enable higher flexibility and capability to the firms and value of the firm will be higher in the market.

\section{Results and Analysis (Model 3 \& 4)}

When the regression is run with the dependent variable ${ }^{4}$, i.e. market value to book value to understand do the firms issuing more debt instrument in the market have higher market value than the firms using lesser or no market debt instrument. Higher the number of debt instruments used we expected a higher value of share in the market as the information flow of the company will reduce the agency costs and the shareholders will discount the equity at a lower rate than the firm where the information flow is lesser. We expect that the firms going to the market will reveal ratings and other information more than that of firms accessing debt from the banks and financial institutions. The fixed effects panel regression is run for three sets of samples, first regression is run using the total number of firms, secondly, the firms using market debt (one source to five sources) and the third being only the firms accessing debt from banks and financial institutions. The model in all the three cases is significant (F-Statistic) at one per cent level with the primary hypothesis that the firms accessing market debt should be able to plan the cash flows and show better performance in terms of ROA and MVBV (Table 5).

The study reveals that there is a negative relationship contrast to the expectations, inferring that the firms accessing market debt have lesser ROA and is significant. The results also reveal that there is a significant negative relationship between the MVBV and the firms with higher number of debt instruments in both of the sample groups i.e. the total firms and the firms issuing one or more debt instruments. [4] observes that if the firms are issuing innovative financing instruments for the sake of innovations or to fool around the investors, the response from the market participants would be that the investors would discount such instruments at an appropriate

Table 4. Showing MVBV, ROA in case of firms using multiple market debt and traditional debt along with total debt.

\begin{tabular}{|c|c|c|c|c|c|c|c|c|c|c|c|}
\hline \multicolumn{2}{|c|}{ Total source } & \multirow{2}{*}{$\begin{array}{c}0 \\
1.671\end{array}$} & \multirow{2}{*}{$\begin{array}{c}1 \\
1.517\end{array}$} & \multirow{2}{*}{$\begin{array}{c}2 \\
1.435\end{array}$} & \multirow{2}{*}{$\begin{array}{c}3 \\
1.707\end{array}$} & \multirow{2}{*}{$\begin{array}{c}4 \\
1.516\end{array}$} & \multirow{2}{*}{$\begin{array}{c}5 \\
2.381\end{array}$} & \multirow[t]{2}{*}{6} & \multirow[t]{2}{*}{7} & \multirow[t]{2}{*}{8} & \multirow[t]{2}{*}{9} \\
\hline Market debt & MVBV & & & & & & & & & & \\
\hline & ROA & 0.038 & 0.035 & 0.029 & 0.033 & 0.022 & 0.043 & & & & \\
\hline & Obs & 13341 & 6013 & 2541 & 716 & 90 & 7 & & & & \\
\hline \multirow[t]{3}{*}{ Traditional debt } & MVBV & 2.448 & 1.v687 & 1.423 & 1.170 & 1.148 & 0.786 & 0.151 & & & \\
\hline & ROA & 0.068 & 0.044 & 0.026 & 0.018 & 0.011 & 0.022 & -0.056 & & & \\
\hline & Obs & 2871 & 8425 & 7423 & 3365 & 566 & 57 & 1.000 & & & \\
\hline \multirow[t]{3}{*}{ Total debt } & MVBV & 2.410 & 1.707 & 1.515 & 1.410 & 1.311 & 1.303 & 1.318 & 1.006 & 0.812 & 0.493 \\
\hline & ROA & 0.068 & 0.042 & 0.033 & 0.029 & 0.021 & 0.020 & 0.017 & 0.017 & 0.006 & 0.023 \\
\hline & Obs & 2608 & 5356 & 6242 & 4495 & 2421 & 1095 & 382 & 91 & 16 & 2 \\
\hline
\end{tabular}

${ }^{3}$ Traditional Debt includes financing from Banks, Financial Institutions, Inter Corporate Loans, Loans from Promoters, Loan from subsidiary and Syndicated Loan from Banks.

${ }^{4}$ Market Debt: 0-No debt; 1 and above in the Market Debt means-there is a sourcing of finance by issuing Debentures or Bonds (Secured/unsecured); Commercial Paper; Fixed Deposits from Public (unique to India); External Commercial Borrowing; Leasing and Hire-Purchase; Traditional Sources Debt: 0-No Traditional Debt; 1 and above in the traditional debt means-there is a sourcing of finance by mobilizing the funds from: 1 Banks; 2-Financial Institutions; 3-Inter Corporate Loans, 4-Loans from Promoters; 5-Loan from subsidiary; 6 Syndicated Loan from Banks. 
Table 5. Regression results for the impact of market sources of debt on the firm performance.

\begin{tabular}{ccc}
\hline Variable & ROA & MVBV \\
GROWTH & $0.082423^{* * *}$ & $1.156253^{* * *}$ \\
TANGIBILITY & $-0.06072^{* * *}$ & $-0.44259^{*}$ \\
SIZE & $0.012069^{* * *}$ & 0.018287 \\
L_TDR & $0.088152^{* * *}$ & $1.280431^{* * *}$ \\
L_ROA & - & 0.274391 \\
NTDS & $-0.24698^{* *}$ & 2.628638 \\
AGE & $0.001682^{* * *}$ & $-0.05003^{* * *}$ \\
MARKET_DUM & $-0.02424^{* * *}$ & $-0.24399^{* * *}$ \\
_CONS & $-3.37842^{* * *}$ & $100.4001^{* * *}$ \\
NUMBER OF OB & 21,863 & 21,863 \\
NUMBR OF GROUPS & 1753 & 1753 \\
OVERALL & 0.0355 & 0.0219 \\
F-STATISTIC & $69.74^{* * *}$ & $30.48^{* * *}$ \\
\hline
\end{tabular}

Note: ${ }^{* * *},{ }^{* *},{ }^{*}$ indicates $1 \%, 5 \%$ and $10 \%$ level of significances respectively.

higher cost making the firm's cost of financing costlier and the value of the firm tends to be lower. On the other hand, the ROA would also increase if, the firms are able to build higher debt capacity by issuing such instruments in the market and derive benefits from savings on tax. The inference that we can draw upon from the results is that the market participants are discounted at a higher rate of discount for the firms that are issuing debt instruments in the market or it could be that the firms borrowing from financial institutions and banks are better able to bargain and mobilize the resources at a much lesser cost than that of market rate. It could be that, the firms issuing instruments in the market are not able to build borrowing capacity and save on taxes.

The tangibility of the firm is significant and influencing the performance of the firm negatively for the performance parameter ROA. It is showing negative relationship with the other performance parameter MVBV, but found to be insignificant in the first and third samples and significant only in the second sample with the access of the firms to market debt. Could be inferred that the firms with higher assets may not be generating high returns and the shareholders are able to choose the firms with lesser asset investment generating higher returns. Size is showing a positive impact on ROA significantly and MVBV is not influenced by the variable size.

Non debt tax shield is influencing negatively the ROA in all the three samples, but it is not significant in the case of second set of sample with access to market debt of the firms. Non-debt tax shield is significant in the case of other two samples inferring that the firms with higher non-debt tax shield have lesser ROA. The variable in the second set of sample is found to be significant in the case of dependent variable being MVBV. Higher the age of the firm, higher the ability to earn, hence the age and ROA are expected to be positively correlated and found to be as per the expectation. Whereas the same variable with the performance parameter being MVBV it is found to be negatively significant for all the three sets of samples.

In the case of both the performance measures the variable is found to be positively significant. We can infer that growth is significantly influencing market value and ROA of the firm. The coefficient is higher in the case of firms with market debt i.e. we can draw an inference that the firms with higher market debt with growth are influencing market value positively and higher than the firms with traditional debt as observed in the case of [6].

\section{Conclusion}

The notions that innovative financing will enable the firms perform better is not acceptable as per our sample results. Innovative financing instruments used by firms should create debt capacity, enabling the firms to save on tax and in turn enable the value of the firm to be higher. Internally too, the optimal usage of such instruments and savings on tax should improve the performance of a firm internally i.e. to increase the ROA of the firm. In our study for the sample it is found to be a quiet contrast to the expectations. 


\section{References}

[1] Cooper, I., Bain, A., Donaldson, A. and Price, L. (1989) New Financial Instruments: Introduction to the Lecture Series. The Chartered Institute of Bankers, Bankers Books Limited, London.

[2] Levine, R. (2002) Bank-Based or Market-Based Financial Systems: Which Is Better? Journal of Financial Intermediation, 11, 398-428. http://dx.doi.org/10.1006/jfin.2002.0341

[3] Myers, S.C. (2001) Capital Structure. The Journal of Economic Perspectives, 15, 81-102. http://dx.doi.org/10.1257/jep.15.2.81

[4] Damodaran, A. (1999) Financing Innovations and Capital Structure Choices. Journal of Applied Corporate Finance, 12, 28-39. http://dx.doi.org/10.1111/j.1745-6622.1999.tb00657.x

[5] Sankarasubramanian, K. (1994) Innovations in Financial Instruments—A Study. The Hindu, Business Line, 4.

[6] Colla, P., Ippolito, F. and Li, K. (2013) Debt Specialization. The Journal of Finance, 68, 2117-2141. http://dx.doi.org/10.1111/jofi.12052

[7] Allen, F., Chakrabarti, R., De, S., Qjan, J.Q. and Qjan, M. (2012) Financing Firms in India. Journal of Financial Intermediation, 21, 409-445. http://dx.doi.org/10.1016/j.jfi.2012.01.003

[8] Giannetti, M., Burkart, M. and Elligensen, T. (2011) What You Sell Is What You Lend? Explaining Trade Credit Contracts. Review of Financial Studies, 24, 1261-1298. http://dx.doi.org/10.1093/rfs/hhn096

[9] Allen, F. and Qian, J. (2010) Comparing Legal and Alternative Institutions in Finance and Commerce. In: Heckman, J. and Nelson, R., Eds., Global Perspectives of Rule of Law, Routledge, New York, 118-144.

[10] Gatev, E. and Strahan, P.E. (2006) Banks’ Advantage in Hedging Liquidity Risk: Theory and Evidence from the Commercial Paper Market. The Journal of Finance, 61, 867-892. http://dx.doi.org/10.1111/j.1540-6261.2006.00857.x

[11] Gilchrist, S. and Himmelberg, C.P. (1995) Evidence on the Role of Cash Flow for Investment. Journal of Monetary Economics, 36, 541-572. http://dx.doi.org/10.1016/0304-3932(95)01223-0

[12] Titman, S. and Wessels, R. (1988) The Determinants of Capital Structure Choice. The Journal of Finance, 43, 1-19. http://dx.doi.org/10.1111/j.1540-6261.1988.tb02585.x

[13] DeAngelo, H. and Masulis, R. (1980) Optimal Capital Structure under Corporate and Personal Taxation. Journal of Financial Economics, 8, 3-29. http://dx.doi.org/10.1016/0304-405X(80)90019-7 